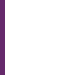

\section{Muscle-specific androgen receptor deletion shows limited actions in myoblasts but not in myofibers in different muscles in vivo}

\author{
Kesha Rana, Maria W S Chiu, Patricia K Russell, Jarrod P Skinner, Nicole K L Lee, \\ Barbara C Fam, Jeffrey D Zajac and Helen E MacLean \\ Department of Medicine, University of Melbourne, Austin Health, Heidelberg, Victoria, Australia
}

Correspondence should be addressed to K Rana

Email

krana@unimelb.edu.au

\begin{abstract}
The aim of this study was to investigate the direct muscle cell-mediated actions of androgens by comparing two different mouse lines. The cre-loxP system was used to delete the DNA-binding activity of the androgen receptor (AR) in mature myofibers (MCK mAR $\triangle \mathrm{ZF2}$ ) in one model and the DNA-binding activity of the AR in both proliferating myoblasts and myofibers ( $\alpha$-actin $m A R^{\Delta z F 2}$ ) in another model. We found that hind-limb muscle mass was normal in MCK mAR $\triangle \mathrm{ZF2}$ mice and that relative mass of only some hind-limb muscles was reduced in $\alpha$-actin mAR ${ }^{\triangle Z F 2}$ mice. This suggests that myoblasts and myofibers are not the major cellular targets mediating the anabolic actions of androgens on male muscle during growth and development. Levator ani muscle mass was decreased in both mouse lines, demonstrating that there is a myofiber-specific effect in this unique androgen-dependent muscle. We found that the pattern of expression of genes including c-myc, Fzd4 and Igf2 is associated with androgen-dependent changes in muscle mass; therefore, these genes are likely to be mediators of anabolic actions of androgens. Further research is required to identify the major targets of androgen actions in muscle, which are likely to include indirect actions via other tissues.
\end{abstract}

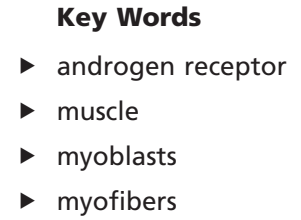

Journal of Molecular Endocrinology (2016) 57, 125-138

\section{Introduction}

Androgens significantly increase skeletal muscle mass; however, due to their potential negative side-effects (Kaufman \& Vermeulen 2005), they are not widely used therapeutically. There is a dose-dependent response of muscle to exogenously administered testosterone in young and elderly men, with increases in muscle size, strength and fiber hypertrophy (Bhasin et al. 2001, Sinha-Hikim et al. 2002), and testosterone treatment in frail elderly men with low-borderline testosterone can prevent loss of limb strength, and increase lean body mass and decrease fat mass (Srinivas-Shankar et al. 2010). Because of these anabolic actions, there is increasing interest in the development of selective androgen receptor (AR) modulators (SARMs) that are anabolic for muscle and bone in the absence of actions in the reproductive tract (Gao et al. 2005, Allan et al. 2008), including studies investigating the target cells of SARM actions in muscle (Dubois et al. 2015). Development of more targeted therapies for increasing muscle mass will be accelerated by a greater understanding of the mechanisms of androgen actions in skeletal muscle.

Published by Bioscientifica Ltd 
Androgens can increase muscle mass, either via exogenous treatment or during development, to achieve peak muscle mass in males vs females (Bhasin et al. 1996, Snyder et al. 1999, Wang et al. 2000, Basaria \& Dobs 2001). These actions are mediated via the AR, as we have shown that male mice with deletion of the second zinc finger (ZF2) of the DNA-binding domain (AR ${ }^{\triangle \mathrm{ZF}}$ ), causing deletion of the DNA binding-dependent actions of the AR (Pang et al. 2011), have reduced muscle mass (MacLean et al. $2008 b$ ). However, it is not known if these anabolic actions occur predominantly during development or postpuberty. Androgens are also required to increase muscle mass in adult males. Androgen withdrawal-dependent muscle atrophy has been demonstrated in both normal men and men with prostate cancer undergoing androgen ablation therapy (Mauras et al. 1998, Basaria et al. 2002), with a similar decrease in muscle mass occurring following orchidectomy in male mice (Axell et al. 2006). Because testosterone levels decline in aging males, this may be one mechanism contributing to age-related sarcopenia.

One of the unanswered questions regarding androgen actions in muscle is whether the AR-regulated pathways are similar or different in androgen-induced muscle growth during development, androgendependent muscle hypertrophy in adulthood and androgen withdrawal-dependent atrophy in adult males. Androgens can drive the commitment of mesenchymal cells into the myogenic lineage (Singh et al. 2003, 2009), and is likely to be one action occurring in males during the development of peak muscle mass. However, the relevance of this action to androgen-dependent muscle hypertrophy in mature muscle is less clear. Adult skeletal muscle fibers are terminally differentiated, and muscle repair and hypertrophy can occur either through an increase in the number of myonuclei, via activation of satellite cells (muscle stem cells) to proliferate as myoblasts, differentiate into myotubes and fuse with myofibers, or via an increase in protein content of postproliferative myofibers. While some studies have shown that androgens increase myoblast proliferation rate and/or delay differentiation (Powers \& Florini 1975, Doumit et al. 1996, Sinha-Hikim et al. 2006, Diel et al. 2008), others suggest the predominant actions are on protein accretion in myofibers (Ferrando et al. 1998, 2002, Chen et al. 2008). Maximal hypertrophic response to muscle overloading requires myofiber $\mathrm{AR}$, but also involves other target cells (Ferry et al. 2014). The relative contribution of these mechanisms in different muscle cell types, as well as the AR target genes mediating these actions (Rana et al. 2014), remains to be determined.
We have previously shown that global AR $\mathrm{AF}^{\mathrm{Z} 2}$ male mice have a $20-25 \%$ decrease in hind-limb muscle mass, as well as a reduction in maximum tetanic force in fasttwitch muscles (MacLean et al. 2008b). This is in contrast to AR-null AR knockout (ARKO) models, which have very mild reductions in muscle mass (Ophoff et al. 2009a). A myofiber-specific AR-null ARKO mouse model has little change in the mass of hind-limb muscles, similar to their global ARKO model, but a reduction in the mass of the highly androgen-sensitive perineal muscle, the levator ani (LA) (Ophoff et al. 2009a,b, Pang et al. 2011). A musclespecific ARKO mouse line with deletion of the AR in both myoblasts and myofibers also has no reduction in hind-limb muscle mass, but reduced LA muscle mass (Chambon et al. 2010). This deletion is associated with loss of hind-limb muscle strength, despite the normal muscle mass (Chambon et al. 2010). A satellite cellspecific ARKO model also shows no reduction in hindlimb muscle mass, but a decrease in LA mass (Dubois et al. 2014, 2015). The phenotypic differences between global AR-null models and our global AR ${ }^{\triangle \mathrm{ZF} 2}$ mice may arise through different methodologies used to assess muscle mass, through different genetic backgrounds, or may be because our model has deletion of DNA bindingdependent actions, but retains non-DNA bindingdependent actions (Pang et al. 2011). Thus, it is possible that deletion of DNA binding-dependent AR actions has a greater effect on muscle anabolism than total loss of AR signaling, and suggests that our $\mathrm{AR}^{\triangle \mathrm{ZF} 2}$ model is useful for identifying the mechanisms underlying the anabolic actions of androgens in muscle. Therefore, to identify the direct muscle cell-mediated actions of androgens, we have compared two different mouse lines, one in which the DNA-binding activity of the AR is deleted only in mature myofibers (MCK mAR ${ }^{\triangle \mathrm{ZF} 2}$ ), and the other in which the AR is deleted in both proliferating myoblasts and myofibers $\left(\alpha\right.$-actin $\left.\mathrm{mAR}^{\Delta \mathrm{ZF} 2}\right)$.

\section{Materials and methods}

\section{Mice}

The exon 3 floxed (ARlox) mouse line (Supplementary Fig. 1A, see section on supplementary data given at the end of this article) was generated as described (Notini et al. 2005). Deletion of exon 3 causes an in-frame deletion of the ZF2 of the DNA-binding domain, and loss of DNA binding-dependent AR signaling (Notini et al. 2005, Pang et al. 2011). Muscle creatine kinase (MCK) $\mathrm{mAR}^{\triangle \mathrm{ZF} 2}$ mice were generated using the MCK-cre line (Bruning et al. 1998)

Published by Bioscientifica Ltd 
(a kind gift of C Ronald Kahn, Joslin Diabetes Center, Boston, MA, USA), which uses the MCK promoter to drive cre expression in postproliferative myofibers. $\alpha$-actin $\mathrm{mAR}^{\triangle \mathrm{ZF2}}$ mice were generated using our previously described $\alpha$-actin cre line (Kaczmarczyk et al. 2003), which uses the human $\alpha$-skeletal actin promoter to drive cre expression in myoblasts. All mouse lines were back-crossed to a congenic C57BL/ 6 background (>10 generations back-cross), and control littermates (ARlox hemizygous males, cre heterozygous males and wildtype (WT) males) were used for both lines. We also analyzed gene expression in gastrocnemius muscle from our previously described global AR $\mathrm{ARF}^{\triangle \mathrm{Z}}$ and androgen deprivation models: WT and global AR ${ }^{\triangle \mathrm{ZF} 2}$,
9 weeks of age, $n \geq 24$, and WT C57BL/6 orchidectomized males treated \pm testosterone for 10 weeks, 8 weeks of age, $n \geq 8$ (Axell et al. 2006, MacLean et al. 2008b). Mice were housed in a conventional facility, and standard chow and water provided ad libitum. Studies were performed with the approval of the Austin Health Animal Ethics Committee.

\section{Voluntary physical activity and food intake}

Voluntary physical activity was measured in mice aged 9-10weeks ( $n=7-9 /$ genotype) using computer-linked running wheels (Lafayette Instruments, Lafayette, IN, USA), as described (Rana et al. 2011), with the number of
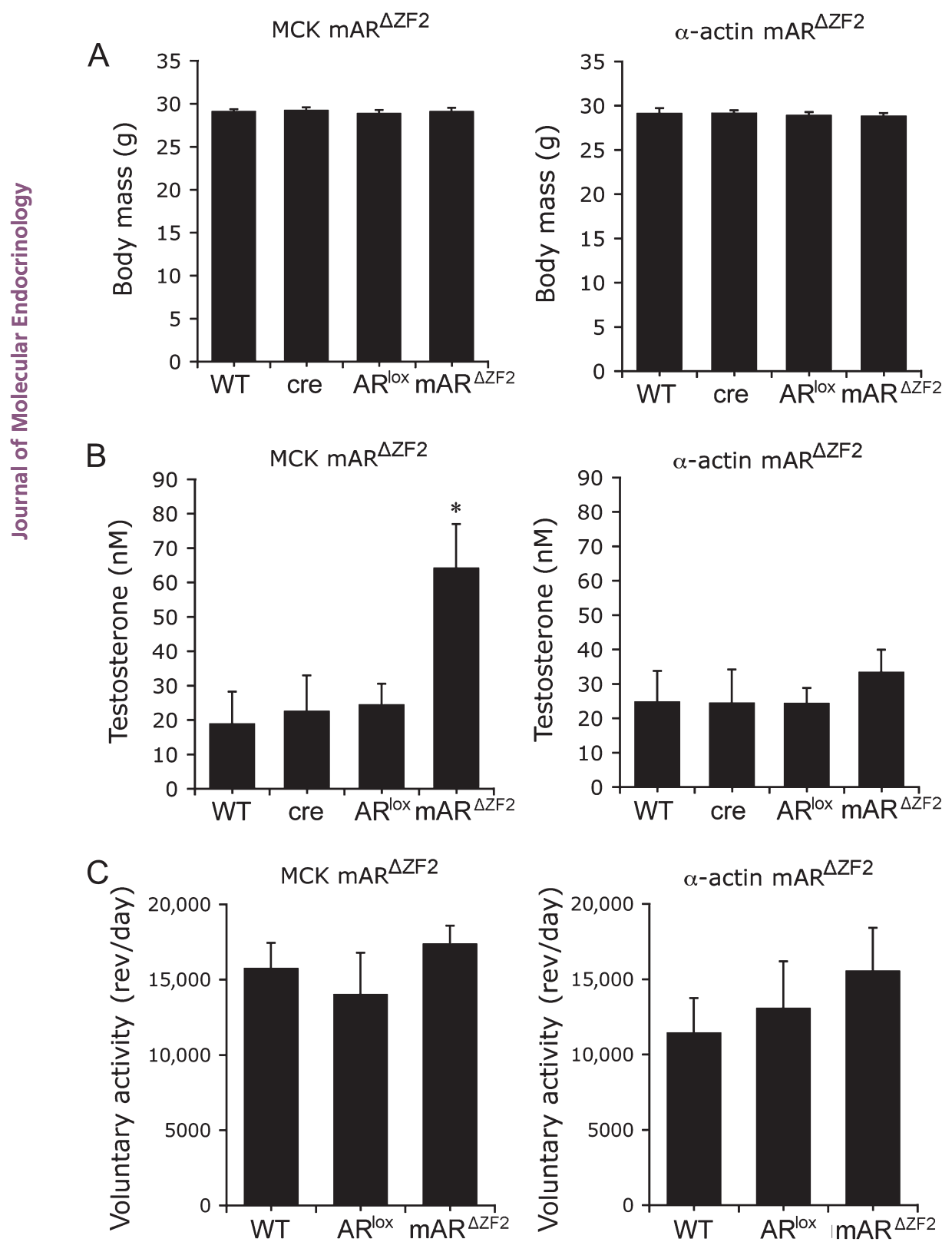

\section{Figure 1}

(A) Body mass ( $n \geq 19 /$ genotype), (B) serum testosterone levels ( $n=12 /$ genotype) and (C) voluntary physical activity ( $n=8-9 /$ genotype) in WT, cre transgenic heterozygous (cre), $A R^{\text {lox }}$ hemizygous ( $A R^{\text {lox }}$ ) and $m A R^{\triangle Z F 2}$ male littermates of the MCK $m A R^{\Delta Z F 2}$ and $\alpha$-actin $m A R^{\triangle Z F 2}$ lines. Mean \pm S.E.M., ${ }^{*} P<0.05$ vs WT, cre heterozygous and $A R^{\text {lox }}$ hemizygous males, one-way ANOVA and Tukey's post hoc test. http://jme.endocrinology-journals.org
DOI: $10.1530 / J M E-15-0320$
๑ 2016 Society for Endocrinology Printed in Great Britain 
wheel revolutions per day determined from the average of readings over 4 days. Food was weighed daily during the wheel-running experiment to determine the average food intake (g/day).

\section{Tissue collection}

Blood was collected by cardiac puncture from mice anesthetized using inhaled isoflurane (Baxter, Deerfield, IL, USA). After clotting on ice, serum was separated by centrifugation, $2 \times 8 \mathrm{~min}$ at $2100 \mathrm{~g}$, and stored at $-20^{\circ} \mathrm{C}$ before analysis. Following blood collection, mice were killed by cervical dislocation and tissues, including heart, kidney, liver, brain, testis, seminal vesicles, extensor digitorum longus (EDL) muscle, tibialis anterior (TA) muscle, soleus (SOL) muscle, gastrocnemius (GAST) muscle, LA muscle, subcutaneous fat, retroperitoneal fat and gonadal fat, were immediately dissected, weighed and snap-frozen in liquid nitrogen, or fixed in $4 \%$ paraformaldehyde. Wet weight of tissues was determined to an accuracy of $0.1 \mathrm{mg}$, from the mean mass bilaterally. Body and tissue mass were measured in 12 week mAR ${ }^{\Delta \mathrm{ZF} 2}$ male mice and male littermate controls.

\section{CDNA synthesis, reverse transcriptase PCR and quantitative real-time PCR}

Total RNA isolation and cDNA synthesis were performed as described (MacLean et al. 2008a). To detect the expression of normal and exon 3-deleted $A R$ genes, reverse transcriptase (RT)-PCR was performed on 500 ng cDNA using primers flanking exon 3 (Notini et al. 2005) (Supplementary Fig. 1A). Quantitative real-time PCR
(Q-PCR) was performed in duplicate using 500 ng cDNA, TaqMan gene expression assays (Applied Biosystems) and calculating relative expression compared with a reference muscle cDNA control using the $\Delta \Delta \mathrm{C}_{\mathrm{T}}$ method, as described previously (MacLean et al. 2008b).

\section{Histology}

Freshly dissected tissues were fixed in $4 \%$ paraformaldehyde in PBS, for $24 \mathrm{~h}$ at $4^{\circ} \mathrm{C}$, washed in PBS and stored in $70 \%$ ethanol before paraffin processing and embedding. Six micron serial sections were cut, and stained with hematoxylin and eosin (H\&E) using standard protocols. Fiber cross-sectional area (CSA) was calculated as described previously (Axell et al. 2006), with CSA dichotomized into groups of $100 \mu \mathrm{m}^{2}(100-200,200-300,300-400,400$ $500,500-600,600-700,700-800,800-900,900-1000$ and $\left.>1000 \mu \mathrm{m}^{2}\right)$. LA sections from two $\mathrm{mAR}^{\triangle \mathrm{ZF} 2}$ males and three WT littermate males, from the two lines, were examined, counting a minimum of 400 fibers per animal and calculating the mean number in each CSA category for both genotypes.

\section{Western analysis}

Protein isolation and polyacrylamide gel electrophoresis were performed as described (Pang et al. 2011), using $30 \mu \mathrm{g}$ protein sample per lane and PVDF membranes. The intensity of all proteins was normalized to $\alpha$-tubulin (Developmental Studies Hybridoma Bank, Iowa City, IA, USA) detected on the same membrane to control for loading. Antihuman myosin heavy chain (MHC) (slow) monoclonal antibody (mAb) (A4.951) (Cho et al. 1993)

Table 1 Fat mass in 12-week-old male littermates from the MCK mAR $\triangle \mathrm{zF2}$ and $\alpha$-actin mAR $\triangle \mathrm{zF2}$ lines.

\begin{tabular}{|c|c|c|c|c|c|c|}
\hline & \multicolumn{3}{|c|}{ MCK mAR ${ }^{\Delta Z F 2}$} & \multicolumn{3}{|c|}{$\alpha$-actin mAR $^{\Delta z F 2}$} \\
\hline & WT & $A R^{\operatorname{lox}}$ & $m A R \triangle Z F 2$ & WT & $A R^{\operatorname{lox}}$ & $m A R \Delta z F 2$ \\
\hline $\begin{array}{l}\text { Subcutaneous fat } \\
\text { (mg) }\end{array}$ & $107.7 \pm 3.8(32)$ & $128.1 \pm 5.7 *(32)$ & $131.4 \pm 5.2 *(20)$ & $110.7 \pm 8.5(20)$ & $127.6 \pm 9.6(24)$ & $124.2 \pm 8.2(27)$ \\
\hline $\begin{array}{l}\text { Subcutaneous } \\
\text { fat/body } \\
\text { weight (mg/g) }\end{array}$ & $3.74 \pm 0.13(32)$ & $4.41 \pm 0.16 *(32)$ & $4.55 \pm 0.15 *(20)$ & $3.88 \pm 0.29(20)$ & $4.38 \pm 0.32(24)$ & $4.36 \pm 0.27(27)$ \\
\hline $\begin{array}{l}\text { Retroperitoneal } \\
\text { fat }(\mathrm{mg})\end{array}$ & $31.5 \pm 2.1(36)$ & $44.7 \pm 3.9 *(32)$ & $51.6 \pm 5.4 *(20)$ & $35.8 \pm 5.1(18)$ & $45.8 \pm 5.5(22)$ & $43.6 \pm 4.7(24)$ \\
\hline $\begin{array}{l}\text { Retroperitoneal } \\
\text { fat/body } \\
\text { weight (mg/g) }\end{array}$ & $1.07 \pm 0.07(22)$ & $1.52 \pm 0.12 *(32)$ & $1.76 \pm 0.17 *(20)$ & $1.25 \pm 0.17(18)$ & $1.56 \pm 0.18(22)$ & $1.51 \pm 0.15(24)$ \\
\hline Gonadal fat (mg) & $164.7 \pm 7.6(22)$ & $206.0 \pm 12.0 *(25)$ & $235.3 \pm 14.5^{* *}(17)$ & $167.3 \pm 12.2(16)$ & $185.3 \pm 14.0(14)$ & $214.0 \pm 14.7 *(19)$ \\
\hline $\begin{array}{l}\text { Gonadal fat/body } \\
\text { weight }(\mathrm{mg} / \mathrm{g})\end{array}$ & $5.78 \pm 0.25(22)$ & $7.08 \pm 0.34 *(25)$ & $8.09 \pm 0.41 * *(17)$ & $5.93 \pm 0.40(16)$ & $6.53 \pm 0.42(14)$ & $7.50 \pm 0.045^{*}(19)$ \\
\hline
\end{tabular}

Mean \pm S.E.M., sample size in parentheses, ${ }^{*} P<0.05, * \star P<0.001$ vs WT (one-way ANOVA, Tukey's or Tamhane's post hoc test).

http://jme.endocrinology-journals.org DOI: 10.1530/JME-15-0320
(C) 2016 Society for Endocrinology Printed in Great Britain
Published by Bioscientifica Ltd 
(Developmental Studies Hybridoma Bank) was used at 1:800, and anti-AR Ab (C-19) (Santa Cruz Biotechnology), anti-c-met (R\&D systems) and anti-Pax7 (Developmental Studies Hybridoma Bank) were used at 1:1000.

\section{Testosterone assay}

Serum testosterone was measured using the DPC CoatA-Count assay (Siemens Medical Solutions Diagnostics, Doncaster, Victoria, Australia), which has a sensitivity of $0.14 \mathrm{nM}$, intra-assay coefficient of variation range of $4-11 \%$, interassay coefficient of variation range of $5.9-12 \%$ and high specificity for testosterone (percentage cross-reactivity with other androgens: androstenedione
0.5\%, $5 \alpha$-dihydrotestosterone $\leq 3.4 \%$, 19-hydroxyandrostenedione $2.0 \%$ and $11 \beta$-hydroxytestosterone $0.8 \%$ ). Mouse serum samples were extracted in hexane:ethyl acetate (17:3) and assayed, as described previously (MacLean et al. 2008a).

\section{Statistical analysis}

For comparison of means for two groups, unpaired Student's $t$-test was performed. For comparison of means for more than two groups, data were analyzed by one-way ANOVA with Tukey's post hoc test, or Tamhane's post hoc test if Levene's test indicated unequal variance within groups. Fiber distributions were analyzed by $\chi^{2}$ analysis. All analyses were performed using SPSS 16.0.
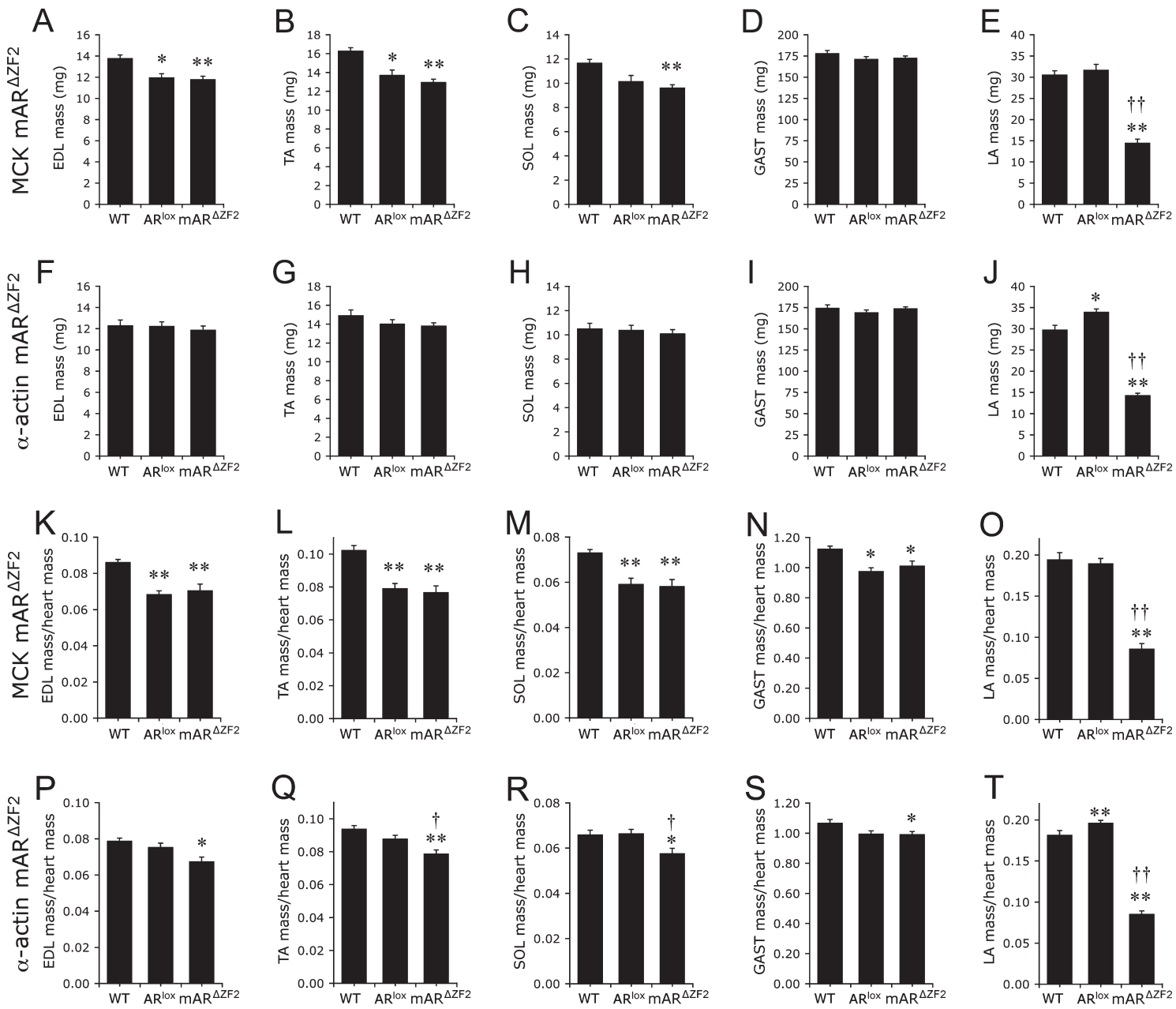

Figure 2

Muscle mass in WT, AR lox hemizygous (AR lox) and mAR ${ }^{\Delta Z F 2}$ male littermates of the $(A, B, C, D, E$ and $K, L, M, N, O)$ MCK-mAR $\triangle$ ZF2 and $(F, G, H, I, J$ and $P, Q$, $R, S, T) \alpha$-actin-mAR $\triangle$ ZF2 lines. (A and F) Extensor digitorum longus (EDL), (B and $G$ ) tibialis anterior (TA), (C and H) soleus (SOL), (D and I) gastrocnemius (GAST), (E and J) levator ani (LA), (K and P) EDL mass/heart mass, (L and Q) TA mass/heart mass (M and R) SOL mass/heart mass, (N and S) GAST mass/ heart mass, $(\mathrm{O}$ and $\mathrm{T})$ LA mass/heart mass. Mean \pm S.E.M., ${ }^{*} P<0.05,{ }^{*} P<0.001$ vs WT; ${ }^{\dagger} P<0.05,{ }^{\dagger \dagger} P<0.001$ vs AR ${ }^{\text {lox }}$ hemizygous, one-Way ANOVA and Tukey's or Tamhane's post hoc test. 


\section{Results}

\section{Generation of myofiber-specific and myoblast/myofiber- specific $A^{\Delta Z F 2}$ males}

Myofiber-specific mAR ${ }^{\triangle Z F 2}$ mice were generated using the MCK-cre line (Bruning et al. 1998), with cre expression under the control of the MCK promoter, which is only expressed in postproliferative myofibers. Myoblast/ myofiber-specific $\mathrm{mAR}^{\triangle \mathrm{ZF} 2}$ mice were generated using the $\alpha$-actin-cre line (Kaczmarczyk et al. 2003). The human skeletal $\alpha$-actin promoter is expressed in myoblasts and myofibers (Schwander et al. 2003), and results in deletion of AR in both myoblasts and myofibers.

The degree of AR gene deletion in muscle from both $\mathrm{mAR}^{\triangle \mathrm{ZF} 2}$ lines was $93-99 \%$ in different hind-limb muscles, as determined by remaining $A R$ gene expression (Supplementary Fig. 1B). To test the tissue specificity of deletion, we used RT-PCR to detect the deleted $\mathrm{AR}^{\triangle \mathrm{ZF} 2}$ allele. In both $\mathrm{mAR}^{\triangle \mathrm{ZF} 2}$ lines, the deleted allele was present in muscle, but could also be amplified from brain and adipose tissue of $\alpha$-actin $\mathrm{mAR}^{\Delta \mathrm{ZF} 2}$ males (Supplementary Fig. 1D). To determine the degree of deletion in nonmuscle tissues, we also measured full-length $A R$ mRNA expression, and found a three-fold increase in $A R$ mRNA in liver of both $\mathrm{mAR}{ }^{\triangle \mathrm{ZF} 2}$ lines; in $\alpha$-actin $\mathrm{MAR}^{\triangle \mathrm{ZF} 2}$ mice, $A R$ expression was reduced by $45 \%$ in brain $(P<0.001)$ and $60 \%$ in subcutaneous fat; however, the latter did not reach statistical significance $(P=0.09)$ (Supplementary Fig. 1E).

\section{Tissue mass in $\mathrm{mAR}^{\Delta \mathrm{ZF} 2}$ males}

For both the myofiber-specific MCK mAR ${ }^{\triangle \mathrm{ZF} 2}$ line and the myoblast/myofiber-specific $\alpha$-actin $\mathrm{mAR}^{\Delta \mathrm{ZF} 2}$ line, $\mathrm{mAR}^{\Delta \mathrm{ZF} 2}$ males were examined at 12 weeks of age, and compared with WT $\left(\mathrm{X}^{+/ \mathrm{Y}}\right)$, cre transgenic heterozygous and $\mathrm{AR}^{\text {lox }}$ hemizygous $\left(\mathrm{AR}^{\mathrm{lox} / \mathrm{Y}}\right)$ male littermates of each line. There was no difference between WT and cre transgenic heterozygotes for any tissue mass examined, including muscle mass (data not shown), so cre values have not been included in results to simplify presentation. In both $\mathrm{mAR}^{\triangle \mathrm{ZF} 2}$ lines, there was no difference in body mass to controls (Fig. 1A). We measured the mass of androgendependent tissues as a biological read-out of androgen action in $\mathrm{mAR}^{\triangle \mathrm{ZF} 2}$ mice, because we previously showed that $\mathrm{AR}^{\mathrm{lox}}$ hemizygous males have a phenotype of hyperandrogenization characterized by an increase in the mass of androgen-dependent tissues including kidney and seminal vesicles (MacLean et al. 2008a). As expected, kidney and seminal vesicle mass was increased in both mAR $\triangle \mathrm{ZF2}$ lines and ARlox males compared with WT, but there was no significant difference between the mAR ${ }^{\Delta \mathrm{ZF} 2}$ and AR ${ }^{\text {lox }}$ groups (Supplementary Table 1). Both the $\alpha$-actin cre and MCK-cre lines express cre in the heart as well as skeletal muscle; however, cardiac mass was normal in $\mathrm{mAR}^{\triangle \mathrm{ZF} 2}$ males of both lines (Supplementary Table 1), in keeping with our data that global $\mathrm{AR}^{\triangle \mathrm{ZF} 2}$ males have normal cardiac mass (MacLean et al. 2008b).

The mass of subcutaneous, retroperitoneal and gonadal fat depots was also determined (Table 1), as we previously showed that global $\mathrm{AR} \triangle \mathrm{ZF2}$ males have increased adiposity (Rana et al. 2011). In the MCK mAR ${ }^{\triangle \mathrm{ZF} 2}$ line, there was a significant increase in subcutaneous, retroperitoneal and gonadal fat pad mass in both $\mathrm{mAR}^{\Delta \mathrm{ZF} 2}$ and $\mathrm{AR}^{\text {lox }}$ males vs WT (Table 1), but no difference between ARlox and mAR ${ }^{\Delta \mathrm{ZF} 2}$ males. A significant increase was also observed in $\alpha$-actin $\mathrm{mAR}^{\triangle \mathrm{ZF} 2}$ gonadal fat vs WT, and a similar increase in mean fat mass values was also observed in other fat depots from the $\mathrm{AR}^{\text {lox }}$ and $\mathrm{mAR}{ }^{\Delta \mathrm{ZF} 2}$ males of the $\alpha$-actin line, although
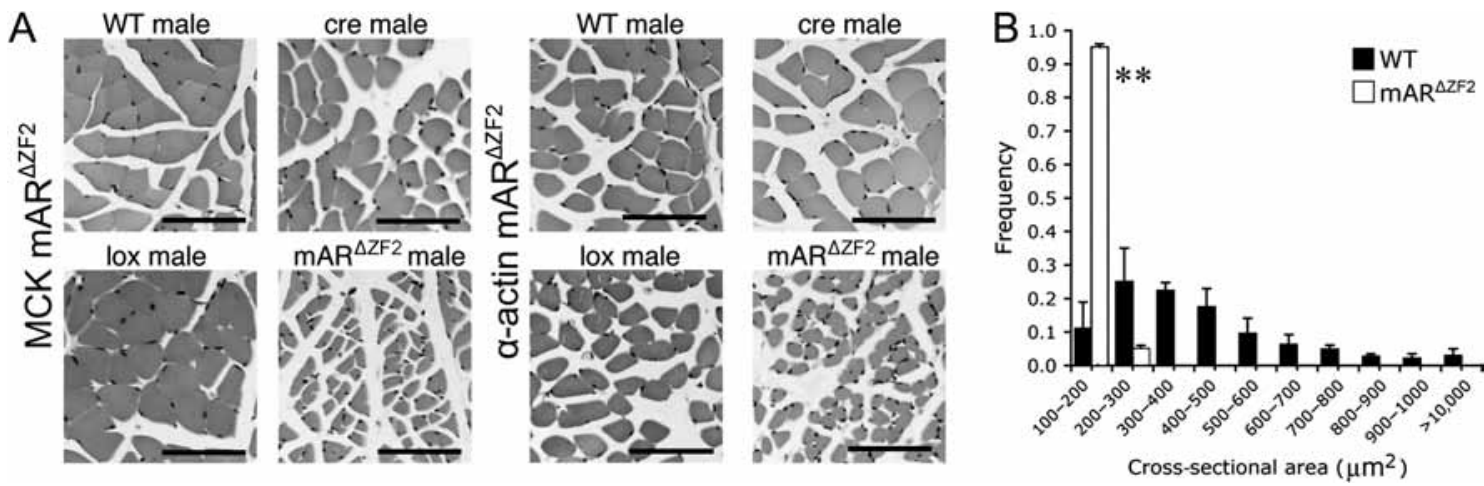

Figure 3

(A) Levator ani muscle cross-sections from WT, cre transgenic heterozygous (cre), ARlox hemizygous (lox) and mAR $\triangle \mathrm{ZF2}$ male littermates of the MCK $m A R^{\triangle Z F 2}$ and $\alpha$-actin $m A R \triangle Z F 2$ lines (H\&E stain, bar $=100 \mathrm{~m}$ ). (B) Distribution of levator ani muscle fiber cross-sectional area from WT and MCK-mAR $\triangle Z F 2$ male littermates ( $n=2-3$ /group), mean \pm S.E.M., $* * P<0.001$ vs WT, $\chi^{2}$ analysis. 
the smaller sample sizes used in this line meant that the study was not sufficiently powered to determine if differences were significant. The increase in fat mass is likely to be due to the floxed AR allele containing the neomycin selection cassette or AR deletion in brain or fat of $\alpha$-actin $\mathrm{mAR}^{\triangle \mathrm{ZF} 2}$ mice, rather than muscle-specific AR deletion.

\section{Serum analysis and voluntary physical activity}

Serum testosterone levels were increased 2.9-fold in MCK mAR $\triangle \mathrm{ZF} 2$ males compared with all littermate controls (Fig. 1B), but $\alpha$-actin $\mathrm{mAR}^{\Delta \mathrm{ZF} 2}$ mice had normal testosterone levels. There was no effect of muscle-specific AR deletion
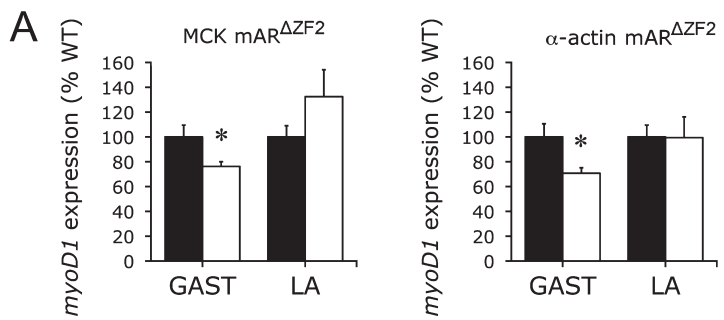

\section{B}
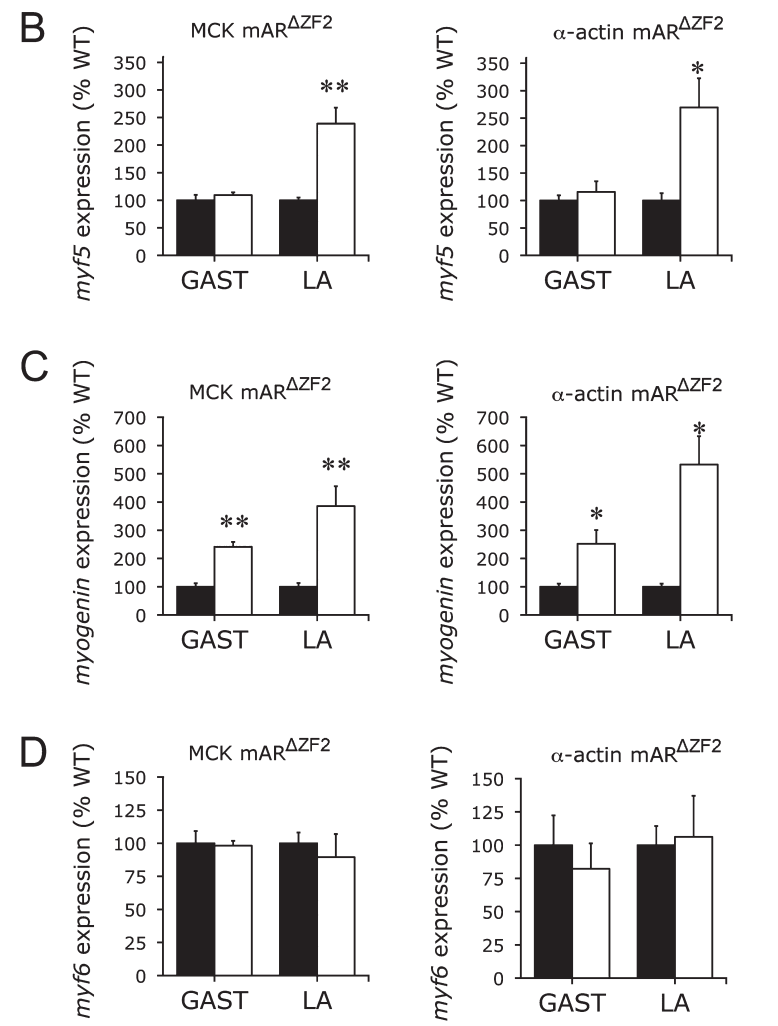

on voluntary physical activity, which was normal in mAR ${ }^{\triangle \mathrm{ZF} 2}$ males of both lines compared with both WT and AR lox controls (Fig. 1C). For both lines, food intake was also normal in $\mathrm{mAR}^{\Delta \mathrm{ZF} 2}$ males (data not shown).

\section{$\mathrm{mAR}^{\Delta \mathrm{ZF2}}$ males have reduced muscle mass and fiber area}

We determined the muscle mass of fast-twitch (EDL and TA), slow-twitch (SOL) and mixed-fiber (GAST) hind-limb muscles, and the highly androgen-dependent LA muscle in the perineum. For the MCK $\mathrm{mAR}^{\triangle \mathrm{ZF2}}$ line, muscle mass was significantly decreased in both $\mathrm{mAR}^{\Delta \mathrm{ZF} 2}$ and $\mathrm{AR}^{\mathrm{lox}}$ males compared with WT for the EDL and TA (Fig. 2A and B), SOL mass was reduced in $\mathrm{MAR}^{\triangle \mathrm{ZF} 2} \mathrm{vs}$ WT (Fig. 2C)
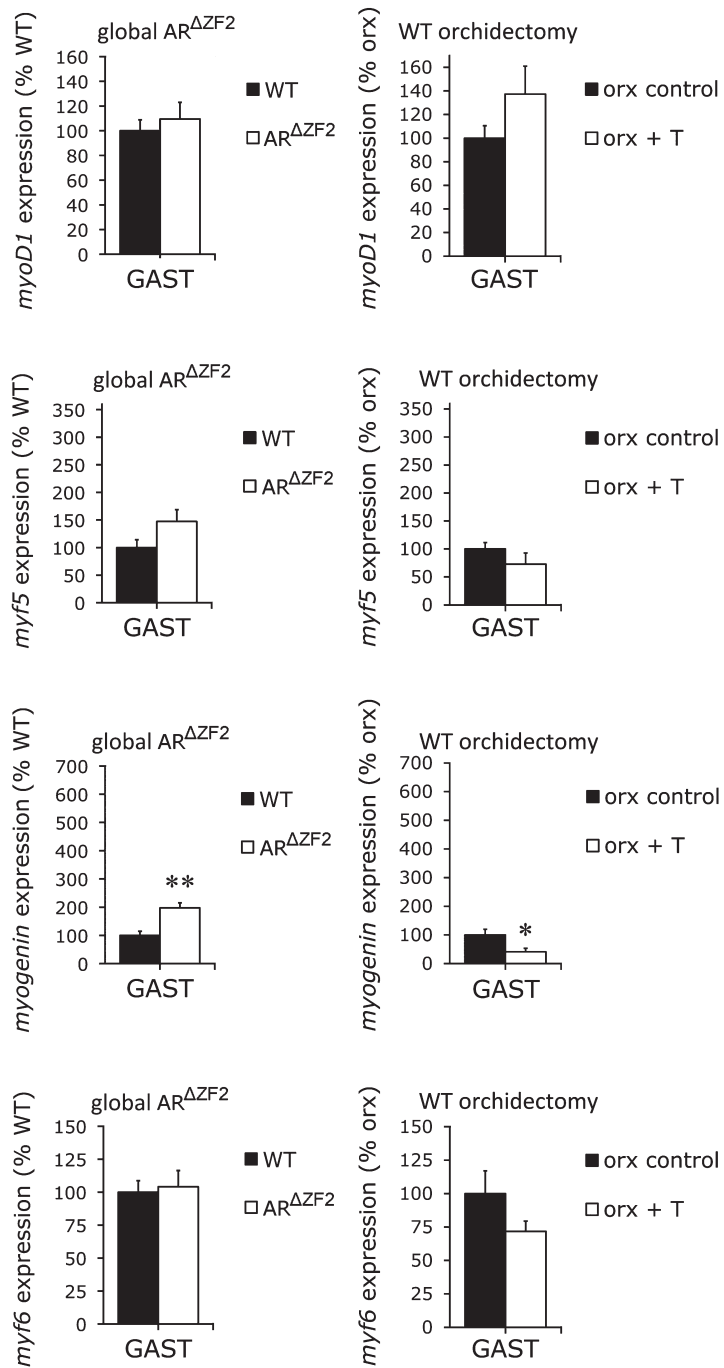

Figure 4

Q-PCR showing expression of myogenic regulatory factors (A) myoD1, (B) myf5, (C) myogenin and (D) myf6 in gastrocnemius (GAST) and levator ani (LA) muscles from WT and AR $\triangle$ ZF2 male littermates of the MCK mAR $\triangle Z$ ZF2 ( $n=11-13 /$ group), $\alpha$-actin mAR ${ }^{\Delta Z F 2}$ ( $n=11-13 / g$ roup) and global AR $\triangle$ ZF2 lines ( $n=11$ /group). Mean \pm S.E.M., $* P<0.05, * * P<0.001$ vs WT control, Student's $t$-test.

http://jme.endocrinology-journals.org DOI: 10.1530/JME-15-0320
๑) 2016 Society for Endocrinology Printed in Great Britain
Published by Bioscientifica Ltd. 
and there was no change in GAST mass (Fig. 2D). For the $\alpha$-actin $\mathrm{mAR}^{\triangle \mathrm{ZF} 2}$ line, there was no change in absolute muscle mass for any of the hind-limb muscles examined (Fig. 2F, G, H and I). In contrast, LA muscle mass was reduced by $\sim 50 \%$ in both $\mathrm{MCK} \mathrm{mAR} \triangle \mathrm{ZF} 2$ and $\alpha$-actin $\mathrm{mAR}^{\triangle \mathrm{ZF} 2}$ males compared with respective WT and $\mathrm{AR}^{\mathrm{lox}}$ controls (Fig. 2E and J).

To control for variations in mouse size, we measured the ratio of muscle mass to heart mass, which is not dependent on DNA-binding activity of the AR (Supplementary Table 1 and (MacLean et al. 2008b)). In the MCK $\mathrm{mAR}^{\triangle \mathrm{ZF} 2}$ line, relative muscle mass was reduced in both MCK $\mathrm{mAR}^{\triangle \mathrm{ZF} 2}$ and $\mathrm{AR}^{\text {lox }}$ controls compared with WT for hind-limb muscles, but no difference between $\mathrm{mAR}^{\triangle \mathrm{ZF} 2}$ and AR ${ }^{\mathrm{lox}}$ (Fig. $2 \mathrm{~K}, \mathrm{~L}, \mathrm{M}$ and $\mathrm{N}$ ), showing no effect of AR deletion. In the $\alpha$-actin $\mathrm{mAR}^{\triangle \mathrm{ZF} 2}$ line, relative hind-limb muscle mass was significantly lower in $\mathrm{mAR} \triangle \mathrm{ZF2}$ compared with both WT and AR ${ }^{\text {lox }}$ controls in the TA (16\% decrease vs WT, $10 \%$ decrease vs $\mathrm{AR}^{\text {lox }}$ ) and SOL (12.5\% decrease vs WT, 13\% decrease vs ARlox) (Fig. 2P, Q, $\mathrm{R}, \mathrm{S}$ and $\mathrm{T})$. Thus, deletion of the AR in both myoblasts and myofibers causes only a modest reduction in relative muscle mass in some hind-limb muscles, which does not occur with deletion in myofibers alone.

There was a marked reduction in LA muscle fiber size in $\mathrm{mAR}^{\triangle \mathrm{ZF} 2}$ males of both lines (Fig. 3A), with a significant shift in distribution to smaller fibers in $\mathrm{mAR}^{\Delta \mathrm{ZF} 2} \mathrm{LA}$ compared with WT males $\left(\chi^{2}=721, d f=9, \quad P<0.001\right)$ (Fig. 3B). There was no difference in the ratio of LA nuclei to fibers between $m A R^{\triangle Z F 2}$, WT and $\mathrm{AR}^{\text {lox }}$ controls for either the $\alpha$-actin $\mathrm{mAR}^{\triangle \mathrm{ZF} 2}$ or MCK mAR ${ }^{\triangle \mathrm{ZF} 2}$ line (data not shown). Global AR ${ }^{\triangle \mathrm{ZF} 2}$ muscle has a switch to a more slow muscle phenotype (MacLean et al. 2008b). Western analysis of $\mathrm{mAR}^{\triangle \mathrm{ZF} 2}$ GAST muscle showed a 30\% decrease in fast MHC levels in $\alpha$-actin $\mathrm{mAR}^{\triangle \mathrm{ZF} 2}$ but not in MCK mAR ${ }^{\triangle \mathrm{ZF} 2}$ GAST (Supplementary Fig. 2A and E), and no change in slow MHC levels in either line (Supplementary Fig. 2B and E), suggesting no consistent switch to a slow phenotype. There was also no consistent change in the levels of two satellite cell markers, Pax7 and c-met (Supplementary Fig. 2C, D and E).

\section{Expression of muscle regulatory factors is regulated by AR deletion}

To determine if the AR in muscle regulates the myogenic regulatory factors (myoD1, myf5, myf6 and myogenin), we measured their gene expression in GAST and LA from both $\mathrm{mAR} \triangle \mathrm{ZF2}$ lines. Expression was also examined in GAST from global AR ${ }^{\triangle \mathrm{ZF} 2}$ males (MacLean et al. 2008b) (LA does not develop in global $\mathrm{AR}^{\triangle \mathrm{ZF} 2}$ ) and in GAST from WT orchidectomized (orx) males treated for 10 weeks with control or testosterone-filled implants (Axell et al. 2006) (Fig. 4). GAST muscle was analyzed as it is a mixed-fiber muscle, so expression changes occurring in either fast- or slow-twitch fibers can be detected, and LA was analyzed because it is a uniquely AR-dependent muscle. Expression of myoD1 was decreased by $25-30 \%$ in GAST from both $\mathrm{mAR}^{\triangle \mathrm{ZF2}}$ lines but was not altered in global AR ${ }^{\triangle \mathrm{ZF} 2}$ GAST; however, there was no difference in myoD1 expression in the LA of both mAR $\triangle \mathrm{ZF2}$ lines (Fig. 4A). In contrast, myf5 expression was unchanged in GAST from mAR $\triangle \mathrm{ZF2}$ and global $\mathrm{AR}^{\triangle \mathrm{ZF} 2}$ males, but increased in LA from both mAR ${ }^{\triangle \mathrm{ZF} 2}$ lines (Fig. 4B). Myogenin expression was elevated in GAST and LA muscles from both $\mathrm{mAR}^{\triangle \mathrm{ZF} 2}$ lines, and also in global $\mathrm{AR}^{\triangle \mathrm{ZF} 2} \mathrm{GAST}$, but decreased in orchidectomized
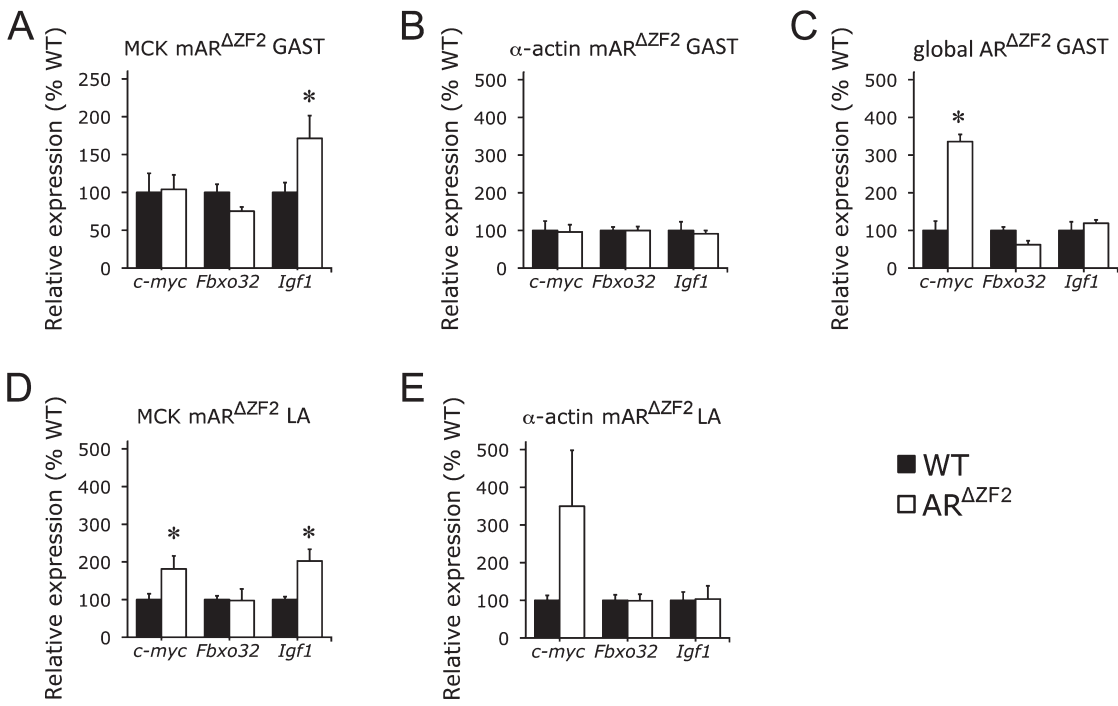
Figure 5
Q-PCR showing expression of c-myc, Fbxo32 and lgf1 in (A, B and C) gastrocnemius (GAST) muscle and $(D$ and $E$ ) levator ani (LA) muscle from WT and $A R^{\triangle Z F 2}$ male littermates of the (A and $\left.D\right)$ MCK $\mathrm{mAR}^{\mathrm{AZF2}}$ ( $n=11-13 /$ group) (B and E) $\alpha$-actin $\mathrm{mAR}^{\triangle Z \mathrm{ZF2}}$ ( $n=11-13$ /group) and (C) global AR $\triangle \mathrm{ZF2}$ lines ( $n=11$ /group). Mean \pm S.E.M., ${ }^{*} P<0.05$ vs WT control, Student's $t$-test.

http://jme.endocrinology-journals.org DOI: 10.1530/JME-15-0320
๑) 2016 Society for Endocrinology Printed in Great Britain 

घT
$\square \mathrm{MAR}$
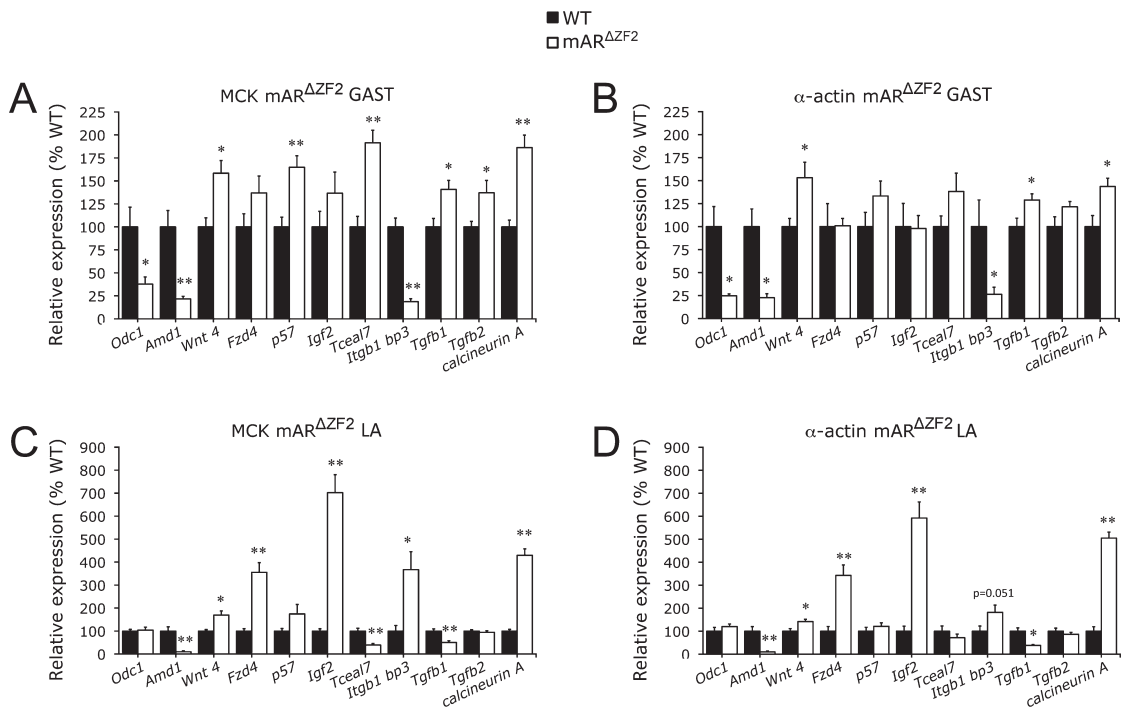

\section{Figure 6}

Q-PCR showing expression of putative AR target genes Odc1, Amd1, Wnt4, Fzd4, p57, Igf2, Tceal7, Itgb1bp3, Tgfb1, Tgfb2 and calcineurin Aa in ( $A$ and $B$ ) gastrocnemius (GAST) muscle and (C and D) levator ani (LA) muscle from WT and $A R \triangle Z F 2$ male littermates of the (A and $B$ ) MCK $m A R^{\triangle Z F 2}$ and $(C$ and $D) \alpha$-actin $m A R^{\Delta z F 2}$ lines ( $n=9-13$ /group). Mean \pm s.E.M., ${ }^{*} P<0.05$, $\star * P<0.001$ vs WT control, Student's $t$-test. males treated with testosterone (Fig. 4C). Expression of myf6 was not altered by AR deletion (Fig. 4D).

\section{Expression of other potential AR target genes}

We examined the expression of other factors that may be important regulatory factors in muscle. Levels of $c-m y c$, which was upregulated in global AR $\triangle \mathrm{ZF2}$ GAST (Fig. 5C), were normal in GAST muscle from both $\mathrm{MAR}^{\triangle \mathrm{ZF} 2}$ lines (Fig. 5A and B), but increased 1.81-fold in the LA of MCK mAR $\triangle \mathrm{ZF2}$ males (Fig. 5D), and mean expression was 3.49 -fold higher in $\alpha$-actin $\mathrm{mAR}^{\triangle \mathrm{ZF} 2} \mathrm{LA}$ compared with WT (Fig. 5E). Fbxo32 (MAFbx/atrogin1) expression was not different between $\mathrm{mAR} \triangle \mathrm{ZF2}$ or global AR $\triangle \mathrm{ZF2}$ males and their respective controls (Fig. 5). In contrast, Igf1 was normal in $\alpha$-actin $\mathrm{mAR}^{\triangle \mathrm{ZF} 2}$ muscles (Fig. $5 \mathrm{~B}$ and E), but increased in both GAST and LA from MCK mAR ${ }^{\triangle \mathrm{ZF} 2}$ males (Fig. 5A and D). Because Igf1 expression was increased only in MCK mAR ${ }^{\triangle Z F 2}$ but not in $\alpha$-actin $\mathrm{mAR}^{\triangle \mathrm{ZF} 2}$ males, we cannot rule out the possibility that this could be a result of estradiol receptor activation, due to the aromatization of the elevated levels of testosterone present only in MCK $\mathrm{mAR}^{\triangle \mathrm{ZF} 2}$ males (Fig. 1B).

For genes we previously showed were differentially expressed in GAST muscle from global AR $\triangle$ ZF2 males and orchidectomized WT males (MacLean et al. 2008b), expression of the polyamine biosynthetic gene Amd1 was decreased in mAR $\triangle \mathrm{ZF} 2$ muscles from both lines (Fig. 6A, B, $\mathrm{C}$ and D); in contrast, Odc1 expression was only decreased in GAST but not in LA muscle from both mAR $\triangle \mathrm{ZF} 2$ lines. p57 was increased in MCK mAR ${ }^{\triangle Z F 2}$ GAST muscle but not in $\alpha$-actin $\mathrm{mAR}^{\triangle \mathrm{ZF} 2}$ muscles, and $I g f 2$ was increased in LA but not in GAST of both lines. Tceal7 showed variable expression, as did expression of $T g f b 1$ and $T g f b 2$ (Fig. 6). Expression of integrin $\beta 1$ binding protein 3 (Itgb1bp3) was decreased in GAST from both $\mathrm{MAR}^{\triangle \mathrm{ZF} 2}$ lines (Fig. 6A and B), but was increased in LA from both lines (Fig. 6C and D). Calcineurin Aa (Ppp3ca) was increased in both GAST and LA muscle from both mAR $\triangle \mathrm{ZF2}$ lines (Fig. 6).

\section{Discussion}

Androgens can have strong anabolic effects in skeletal muscle; however, the major target cell mediating these actions has not been elucidated. We previously showed that global deletion of the DNA binding-dependent actions of the $\mathrm{AR}$ in male mice (global $\mathrm{AR}^{\triangle \mathrm{ZF}}$ ) causes a $15-20 \%$ reduction in hind-limb skeletal muscle mass (MacLean et al. 2008b). However, in this study, we now show that deletion of AR DNA binding-dependent actions in myofibers (MCK mAR ${ }^{\triangle \mathrm{ZF} 2}$ ) or in myoblasts and myofibers ( $\alpha$-actin $\mathrm{mAR}^{\Delta \mathrm{ZF} 2}$ ) has little effect on hind-limb muscle mass. This suggests that myoblasts and myofibers are not the major cellular targets mediating the anabolic actions of androgens on male muscle during growth and development. The highly androgen-dependent LA muscle has a $50 \%$ reduction in mass in both $\mathrm{mAR}^{\Delta \mathrm{ZF} 2}$ lines, associated with decreased fiber cross-sectional area. Although the LA is used widely as a model muscle to assess the anabolic actions of androgens and SARMs, our results show that it differs in both the androgen dependence of its mass as well as the pattern of AR target gene expression compared with hind-limb muscles, as we have previously shown (Rana et al. 2014). These facts raise 
questions regarding the relevance of results obtained from the LA for therapies that will ultimately be required to increase mass and strength in clinically significant limb and postural muscles.

The primary cellular targets of androgen action in skeletal muscle remain unresolved (Kadi 2008). Different studies have suggested that androgens act on satellite cells or myoblasts to increase the number of myonuclei (Mulvaney et al. 1988, Joubert et al. 1994, Joubert \& Tobin $1995)$ or act on myofibers to increase protein content (Sheffield-Moore et al. 1999, Ferrando et al. 2002, Chen et al. 2008, Ophoff et al. 2009b). However, despite the fact that the AR is deleted by $\geq 93 \%$ in hind-limb muscles of both $m A R^{\triangle Z F 2}$ lines in our study, muscle mass is virtually normal with only relative muscle mass decreased in $\alpha$-actin $\mathrm{mAR} \triangle \mathrm{ZF2}$ TA and soleus, but all other hind-limb muscles not different to $\mathrm{AR}^{\operatorname{lox}}$ controls. This suggests a modest muscle-specific effect of deletion of the AR in myoblasts but not in myofibers, to increase muscle mass in only specific hind-limb muscles. It is also possible that hind-limb muscle mass is altered in $\alpha$-actin $\mathrm{AR}^{\triangle \mathrm{ZF} 2}$ males in part due to the effects of nonspecific AR deletion of AR in the brain, where $A R$ expression is decreased by $45 \%$, or subcutaneous fat (decreased by 60\%). The minor changes in muscle mass are in contrast to our global $\mathrm{AR}^{\triangle \mathrm{ZF2}}$ mice, in which muscle mass was decreased in all hindlimb muscles (MacLean et al. 2008b) and indicates that the anabolic actions of androgens must occur through target cells other than myoblasts and myofibers, either in mesenchymal precursors, or other tissues such as the CNS.

The highly androgen-dependent LA muscle was reduced by $50 \%$ in both $\mathrm{mAR}^{\triangle \mathrm{ZF} 2}$ lines, showing androgen actions on myofibers in the LA only, which must regulate protein content and contribute to half the mass. The fact that the LA fails to develop at all in the global AR $\triangle \mathrm{ZF2}$ (MacLean et al. 2008b), or in mice with AR deleted in undifferentiated embryonic perineal mesenchymal cells (Ipulan et al. 2014), is highly suggestive that androgens also act in the early muscle cell lineage, either in commitment to the myogenic lineage (Singh et al. 2003) or on early muscle satellite cells in this muscle. AR-positive fibroblasts are present in LA, and androgen actions on these fibroblasts could also contribute to muscle development and maintenance of muscle mass (Dubois et al. 2015).

We examined a number of potential AR target genes to determine if their expression would change associated with androgen/AR-dependent changes in muscle mass in the LA (decreased mass) and not the GAST (no change in mass). Of the myogenic regulatory factors, myogenin showed increased expression in LA but was also increased in the GAST of both $m A R \triangle Z F 2$ lines and global AR $\triangle \mathrm{ZF}$. Myogenin drives terminal differentiation of myoblasts into myotubes (Hasty et al. 1993, Nabeshima et al. 1993, Patapoutian et al. 1995, Rawls et al. 1995), and we previously showed that myogenin is repressed by androgens in vitro and in vivo (Rana et al. 2014). The current data

Table 2 Gene expression in muscle in MCK mAR $\triangle \mathrm{ZF2}$ and $\alpha$-actin mAR $\triangle \mathrm{ZF2}$ lines, global AR $\triangle \mathrm{ZF2}$ (MacLean et al. 2008b), and testosterone-treated orchidectomy models (Axell et al. 2006, Rana et al. 2011).

\begin{tabular}{|c|c|c|c|c|}
\hline Gene & Function in muscle & mAR ${ }^{\Delta Z F 2}$ LA, not GAST & $\begin{array}{l}\text { Regulated in } \\
\text { global AR }{ }^{\Delta \mathrm{ZF2}} \text { GAST }\end{array}$ & $\begin{array}{c}\text { Orchidectomy + testosterone } \\
\text { GAST }\end{array}$ \\
\hline Myf5 & Myogenic commitment & $\uparrow$ & $\leftrightarrow$ & $\leftrightarrow$ \\
\hline$c-m y c$ & $\begin{array}{l}\text { Cell proliferation, satellite cell } \\
\text { activation }\end{array}$ & $\uparrow$ & $\uparrow$ & $\downarrow$ \\
\hline Fzd4 & $\begin{array}{l}\text { Myogenic differentiation, satellite cell } \\
\text { activation }\end{array}$ & $\uparrow$ & $\uparrow$ & $\downarrow$ \\
\hline $\lg f 2$ & Myoblast differentiation & $\uparrow$ & $\uparrow$ & $\downarrow$ \\
\hline Itgb1bp3 & Myoblast differentiation (-ve) & $\uparrow(\downarrow$ in GAST) & $\downarrow$ & $\leftrightarrow$ \\
\hline \multirow[t]{2}{*}{ Tgfb1 } & $\begin{array}{l}\text { Myoblast differentiation (-ve), } \\
\text { satellite cell activation (-ve) }\end{array}$ & $\downarrow(\uparrow$ in GAST) & Not determined & Not determined \\
\hline & & $\mathrm{mAR}^{\Delta \mathrm{ZF2}}$ LA and GAST & Global AR ${ }^{\Delta Z F 2}$ GAST & $\begin{array}{c}\text { Orchidectomy + testosterone } \\
\text { GAST }\end{array}$ \\
\hline Myogenin & Terminal myoblast differentiation & $\uparrow$ & $\uparrow$ & $\downarrow$ \\
\hline Wnt4 & $\begin{array}{l}\text { Myogenic differentiation, satellite cell } \\
\text { activation }\end{array}$ & $\uparrow$ & $\uparrow$ & $\downarrow$ \\
\hline Calcineurin $A$ & Myoblast differentiation & $\uparrow$ & $\uparrow$ & $\downarrow$ \\
\hline \multirow[t]{2}{*}{ Amd1 } & Polyamine biosynthesis & $\downarrow$ & $\downarrow$ & $\uparrow$ \\
\hline & & mAR ${ }^{\Delta Z F 2}$ GAST, not LA & Global AR ${ }^{\Delta Z F 2}$ GAST & $\begin{array}{l}\text { Orchidectomy + testosterone } \\
\text { GAST }\end{array}$ \\
\hline Odc1 & $\begin{array}{l}\text { Polyamine biosynthesis, myoblast } \\
\text { proliferation }\end{array}$ & $\downarrow$ & $\downarrow$ & $\uparrow$ \\
\hline p57 & Myoblast differentiation & $\uparrow(\mathrm{MCK}$ only) & $\uparrow$ & $\leftrightarrow$ \\
\hline
\end{tabular}

http://jme.endocrinology-journals.org DOI: 10.1530/JME-15-0320
(C) 2016 Society for Endocrinology Printed in Great Britain 
demonstrate that androgens act via the AR in myofibers to repress myogenin expression. However, the fact that this loss of repression occurred in the mAR $\triangle \mathrm{ZF2}$ GAST muscles, while GAST mass was normal, indicates that this change in expression is not sufficient to impact on muscle mass in the absence of other changes (Rana et al. 2014). In contrast, Myf5 was upregulated in the LA muscle of both $\mathrm{mAR}^{\triangle \mathrm{ZF} 2}$ lines but not in GAST muscle, suggesting that this regulation is specific to the LA. Myf5 may be one of the genes mediating the androgen effects on muscle mass in the LA, but the fact that it is not upregulated in global $\mathrm{AR}^{\triangle \mathrm{ZF} 2}$ hind-limb muscle suggests that this regulatory pathway in the LA is not widely applicable to or representative of all skeletal muscle (Rana et al. 2014).

We identified a group of genes that showed a consistent pattern of regulation by androgens and the AR in muscles that had decreased mass (Table 2, Supplementary Fig. 3). To rule out the confounding effects of the elevated serum testosterone in the MCK mAR ${ }^{\triangle \mathrm{ZF} 2}$ males, or off-target AR deletion in $\alpha$-actin $\mathrm{mAR}^{\triangle \mathrm{ZF} 2}$ males, we have focused only on genes that were altered in both $\mathrm{mAR}^{\triangle \mathrm{ZF} 2}$ models and/or global $\mathrm{mAR}^{\triangle \mathrm{ZF} 2}$ mice (MacLean et al. 2008b). A group of genes were upregulated only in LA but not in GAST of both mAR ${ }^{\Delta \mathrm{ZF} 2}$ lines including $m y f 5$, $c-m y c, F z d 4$, Igf2 and Itgb1bp3; Tgfb1 was decreased in LA but not in GAST. Of these genes, c-myc, Fzd4 and Igf2 were also upregulated in global AR ${ }^{\triangle \mathrm{ZF} 2} \mathrm{GAST}$, in which muscle mass is reduced by $19 \%$ (MacLean et al. 2008b) (Table 2). c-myc, Fzd4 and Igf2 were also downregulated in GAST muscle from orchidectomized males treated with testosterone (Table 2), in which hind-limb muscle mass differs by 18-27\% (Axell et al. 2006). This suggests that all these genes are repressed by the androgen/AR pathway in skeletal muscle associated with androgen-dependent regulation of muscle mass. Therefore, these genes are possible mediators of the anabolic actions of androgens in these muscles, through control of cell proliferation ( $c$ myc) (Kelly et al. 1983, Falcone et al. 1985), regulation of myoblast differentiation (Igf2) (Wilson \& Rotwein 2006, Schiaffino \& Mammucari 2011) and myogenic differentiation or activation of satellite cells (Fzd4) (Rudnicki \& Williams 2015).

Another group of genes was consistently regulated by androgens and the AR in both GAST and LA muscles. Myogenin, Wht 4 and calcineurin A were upregulated in both $\mathrm{mAR}^{\triangle \mathrm{ZF} 2}$ lines and global $\mathrm{AR}^{\triangle \mathrm{ZF} 2}$, and downregulated in testosterone-treated orchidectomized male mice (MacLean et al. 2008b). Conversely, Amd1 was downregulated in both mAR ${ }^{\triangle \mathrm{ZF} 2}$ GAST and LA and in global AR ${ }^{\triangle \mathrm{ZF} 2}$ mice, and upregulated in testosterone-treated orchidectomized males (Table 2). The fact that these genes were consistently regulated by deletion of the AR in all muscles of both $\mathrm{mAR}^{\triangle \mathrm{ZF} 2}$ lines and global AR ${ }^{\triangle \mathrm{ZF} 2}$ mice, and by androgens in the testosterone-treated orchidectomy model, suggests that they are regulated by the androgen-AR pathway in myofibers. However, because GAST muscle mass was not altered by muscle-specific AR deletion, the contribution of these genes to regulation of muscle mass must be minimal. Similarly, the altered regulation of genes such as $\operatorname{Odc1}$ and $p 57$ in GAST but not in LA of mAR $\triangle \mathrm{ZF2}$ lines (Table 2) suggests not only that there is differential regulation of these genes in different muscles, but also that these changes in expression does not alter muscle mass.

To address whether the same genes are regulated by androgens/AR in the development of peak muscle mass, and the maintenance of muscle mass that prevents androgen withdrawal-dependent atrophy in adult males, we compared the genes dysregulated by AR deletion vs orchidectomy/testosterone treatment. Of the genes that were associated with decreased LA mass in both $\mathrm{mAR}^{\Delta \mathrm{ZF2}}$ lines, $c-m y c, F z d 4$ and $I g f 2$ were also regulated by testosterone treatment of orchidectomized males, whereas Myf5 and Itgb1bp3 were not (Table 2). This shows that there is some overlap in the pathways that androgens/AR regulate to achieve peak muscle mass and to maintain mass in adulthood, but also other genes are only altered when the AR is deleted throughout development, but not following androgen withdrawal/replacement in adulthood. The genes that are regulated by androgens and the AR in all models may provide the best targets for therapeutic targeting, to maximize the possibility of increasing muscle mass.

One of the most striking findings of all muscle-specific ARKO models is their relative lack of effect on muscle mass. Most mARKO models have focused on the LA muscle because it is atypical in its androgen-responsiveness and shows a large reduction in muscle mass, whereas hind-limb muscle mass is normal or near-normal (Ophoff et al. 2009b, Chambon et al. 2010, Dubois et al. 2014). Our mAR $\triangle \mathrm{ZF2}$ lines also show a similar lack of hind-limb muscle phenotype, despite the fact that global AR $\triangle \mathrm{ZF2}$ males have a $15-20 \%$ decrease in hind-limb muscle mass (MacLean et al. 2008b). The phenotypic differences between the models may arise through different methodologies used to assess muscle mass, mixed genetic backgrounds of the AR-null mARKO models and also the fact that our model has deletion of DNA binding-dependent actions, but retains potential DNA binding-independent actions, because mutant AR protein is expressed. However, the relative lack of effect on muscle mass of AR deletion in satellite cells, myoblasts

Published by Bioscientifica Ltd. 
and/or myofibers in all the muscle-specific models is strongly suggestive that the major target of androgen action is in other target tissues. Androgen effects on other tissues that could contribute to regulation of muscle mass could include actions in the CNS. We previously showed that global $\mathrm{AR}^{\triangle \mathrm{ZF} 2}$ male mice have a $70 \%$ reduction in voluntary physical activity (Rana et al. 2011). The fact that the two mAR ${ }^{\triangle \mathrm{ZF} 2}$ lines have normal voluntary activity demonstrates that this effect is not due to androgens acting through the AR in myoblasts or myofibers, and is, therefore, more likely to be mediated through the AR in other tissues. AR-null CNS-ARKO male mice have increased locomotor activity (cage movement), a measure of incidental ambulatory activity (Raskin et al. 2009). In contrast, voluntary physical activity (wheel-running) is decreased in our global AR $\triangle \mathrm{ZF} 2$ model. Incidental ambulatory and voluntary physical activities have opposing regulation by estradiol in aromatase knockout mice (Hill et al. 2007); therefore, it is possible that they are also regulated in an opposing manner by the AR in the CNS.

In conclusion, our mouse models show that androgens acting through the DNA-binding actions of the AR do not play a major role in myoblasts or myofibers to regulate skeletal muscle mass. While muscle-specific AR deletion causes a 50\% reduction in LA muscle mass, relative hind-limb muscle mass is only decreased in the TA and SOL of $\alpha$-actin $\mathrm{mAR}^{\Delta \mathrm{ZF} 2}$ but not in MCK mAR ${ }^{\triangle \mathrm{ZF} 2}$ males, indicating only a very modest action through myoblasts in some hind-limb muscles. We found that the pattern of expression of genes including $c-m y c, F z d 4$ and $I g f 2$ is associated with androgen-dependent changes in muscle mass; therefore, these genes are likely to be mediators of anabolic actions of androgens. However, the differential effects of AR deletion on muscle mass and gene expression in the LA compared with hind-limb muscles suggests that the LA is not a good muscle model to study general mechanisms of androgen actions in skeletal muscle. Further research is required to identify the major cellular and molecular targets of androgen actions in muscle, which are likely to include indirect actions via other tissues.

\section{Supplementary data}

This is linked to the online version of the paper at http://dx.doi.org/10.1530/ JME-15-0320.

\section{Declaration of interest}

The authors declare that there is no conflict of interest that could be perceived as prejudicing the impartiality of the research reported.

\section{Funding}

This research was supported by NHMRC Project Grant \#350334, a Sir Edward Dunlop Medical Research Foundation Grant, and HEM was supported by NHMRC Career Development Award \#359226.

\section{References}

Allan G, Sbriscia T, Linton O, Lai MT, Haynes-Johnson D, Bhattacharjee S, Ng R, Sui Z \& Lundeen S 2008 A selective androgen receptor modulator with minimal prostate hypertrophic activity restores lean body mass in aged orchidectomized male rats. Journal of Steroid Biochemistry and Molecular Biology 110 207-213. (doi:10.1016/j.jsbmb.2007.10.012)

Axell AM, MacLean HE, Plant DR, Harcourt LJ, Davis JA, Jimenez M, Handelsman DJ, Lynch GS \& Zajac JD 2006 Continuous testosterone administration prevents skeletal muscle atrophy and enhances resistance to fatigue in orchidectomized male mice. American Journal of Physiology: Endocrinology and Metabolism 291 E506-E516. (doi:10.1152/ajpendo.00058.2006)

Basaria S \& Dobs AS 2001 Hypogonadism and androgen replacement therapy in elderly men. American Journal of Medicine $110563-572$. (doi:10.1016/S0002-9343(01)00663-5)

Basaria S, Lieb J 2nd, Tang AM, DeWeese T, Carducci M, Eisenberger M \& Dobs AS 2002 Long-term effects of androgen deprivation therapy in prostate cancer patients. Clinical Endocrinology 56 779-786. (doi:10.1046/j.1365-2265.2002.01551.x)

Bhasin S, Storer TW, Berman N, Callegari C, Clevenger B, Phillips J, Bunnell TJ, Tricker R, Shirazi A \& Casaburi R 1996 The effects of supraphysiologic doses of testosterone on muscle size and strength in normal men. New England Journal of Medicine 335 1-7. (doi:10.1056/NEJM199607043350101)

Bhasin S, Woodhouse L, Casaburi R, Singh AB, Bhasin D, Berman N, Chen X, Yarasheski KE, Magliano L, Dzekov C, et al. 2001 Testosterone dose-response relationships in healthy young men. American Journal of Physiology: Endocrinology and Metabolism 281 E1172-E1181.

Bruning JC, Michael MD, Winnay JN, Hayashi T, Horsch D, Accili D, Goodyear LJ \& Kahn CR 1998 A muscle-specific insulin receptor knockout exhibits features of the metabolic syndrome of NIDDM without altering glucose tolerance. Molecular Cell 2 559-569. (doi:10.1016/S1097-2765(00)80155-0)

Chambon C, Duteil D, Vignaud A, Ferry A, Messaddeq N, Malivindi R, Kato S, Chambon P \& Metzger D 2010 Myocytic androgen receptor controls the strength but not the mass of limb muscles. PNAS $\mathbf{1 0 7}$ 14327-14332. (doi:10.1073/pnas.1009536107)

Chen Y, Lee NK, Zajac JD \& MacLean HE 2008 Generation and analysis of an androgen-responsive myoblast cell line indicates that androgens regulate myotube protein accretion. Journal of Endocrinological Investigation 31 910-918. (doi:10.1007/ BF03346441)

Cho M, Webster SG \& Blau HM 1993 Evidence for myoblast-extrinsic regulation of slow myosin heavy chain expression during muscle fiber formation in embryonic development. Journal of Cell Biology 121 795-810. (doi:10.1083/jcb.121.4.795)

Diel P, Baadners D, Schlupmann K, Velders M \& Schwarz JP 2008 C2C12 myoblastoma cell differentiation and proliferation is stimulated by androgens and associated with a modulation of myostatin and Pax7 expression. Journal of Molecular Endocrinology 40 231-241. (doi:10.1677/JME-07-0175)

Doumit ME, Cook DR \& Merkel RA 1996 Testosterone up-regulates androgen receptors and decreases differentiation of porcine myogenic satellite cells in vitro. Endocrinology 137 1385-1394. (doi:10.1210/en.137.4.1385) http://jme.endocrinology-journals.org

DOI: 10.1530/JME-15-0320
๑) 2016 Society for Endocrinology Printed in Great Britain 
Dubois V, Laurent MR, Sinnesael M, Cielen N, Helsen C, Clinckemalie L, Spans L, Gayan-Ramirez G, Deldicque L, Hespel P, et al. 2014 A satellite cell-specific knockout of the androgen receptor reveals myostatin as a direct androgen target in skeletal muscle. FASEB Journal 28 2979-2994. (doi:10.1096/fj.14-249748)

Dubois V, Simitsidellis I, Laurent MR, Jardi F, Saunders PT, Vanderschueren D \& Claessens F 2015 Enobosarm (GTx-024) modulates adult skeletal muscle mass independently of the androgen receptor in the satellite cell lineage. Endocrinology $1564522-4533$. (doi:10.1210/en.2015-1479)

Falcone G, Tato F \& Alema S 1985 Distinctive effects of the viral oncogenes myc, erb, fps, and src on the differentiation program of quail myogenic cells. PNAS 82 426-430. (doi:10.1073/pnas.82.2.426)

Ferrando AA, Tipton KD, Doyle D, Phillips SM, Cortiella J \& Wolfe RR 1998 Testosterone injection stimulates net protein synthesis but not tissue amino acid transport. American Journal of Physiology $\mathbf{2 7 5}$ E864-E871.

Ferrando AA, Sheffield-Moore M, Yeckel CW, Gilkison C, Jiang J, Achacosa A, Lieberman SA, Tipton K, Wolfe RR \& Urban RJ 2002 Testosterone administration to older men improves muscle function: molecular and physiological mechanisms. American Journal of Physiology: Endocrinology and Metabolism 282 E601-E607. (doi:10.1152/ajpendo.00362.2001)

Ferry A, Schuh M, Parlakian A, Mgrditchian T, Valnaud N, Joanne P, Butler-Browne G, Agbulut O \& Metzger D 2014 Myofiber androgen receptor promotes maximal mechanical overload-induced muscle hypertrophy and fiber type transition in male mice. Endocrinology 155 4739-4748. (doi:10.1210/en.2014-1195)

Gao W, Reiser PJ, Coss CC, Phelps MA, Kearbey JD, Miller DD \& Dalton JT 2005 Selective androgen receptor modulator treatment improves muscle strength and body composition and prevents bone loss in orchidectomized rats. Endocrinology 146 4887-4897. (doi:10.1210/en.2005-0572)

Hasty P, Bradley A, Morris JH, Edmondson DG, Venuti JM, Olson EN \& Klein WH 1993 Muscle deficiency and neonatal death in mice with a targeted mutation in the myogenin gene. Nature 364 501-506. (doi:10.1038/364501a0)

Hill RA, McInnes KJ, Gong EC, Jones ME, Simpson ER \& Boon WC 2007 Estrogen deficient male mice develop compulsive behavior. Biological Psychiatry 61 359-366. (doi:10.1016/j. biopsych.2006.01.012)

Ipulan LA, Suzuki K, Sakamoto Y, Murashima A, Imai Y, Omori A, Nakagata N, Nishinakamura R, Valasek P \& Yamada G 2014 Nonmyocytic androgen receptor regulates the sexually dimorphic development of the embryonic bulbocavernosus muscle. Endocrinology 155 2467-2479. (doi:10.1210/en.2014-1008)

Joubert Y \& Tobin C 1995 Testosterone treatment results in quiescent satellite cells being activated and recruited into cell cycle in rat levator ani muscle. Developmental Biology 169 286-294. (doi:10.1006/ dbio.1995.1144)

Joubert Y, Tobin C \& Lebart MC 1994 Testosterone-induced masculinization of the rat levator ani muscle during puberty. Developmental Biology 162 104-110. (doi:10.1006/dbio.1994.1070)

Kaczmarczyk SJ, Andrikopoulos S, Favaloro J, Domenighetti AA, Dunn A, Ernst M, Grail D, Fodero-Tavoletti M, Huggins CE, Delbridge LM, et al. 2003 Threshold effects of glucose transporter-4 (GLUT4) deficiency on cardiac glucose uptake and development of hypertrophy. Journal of Molecular Endocrinology 31 449-459. (doi:10.1677/jme.0.0310449)

Kadi F 2008 Cellular and molecular mechanisms responsible for the action of testosterone on human skeletal muscle. A basis for illegal performance enhancement. British Journal of Pharmacology $\mathbf{1 5 4}$ 522-528. (doi:10.1038/bjp.2008.118)

Kaufman JM \& Vermeulen A 2005 The decline of androgen levels in elderly men and its clinical and therapeutic implications. Endocrine Reviews 26 833-876. (doi:10.1210/er.2004-0013)
Kelly K, Cochran BH, Stiles CD \& Leder P 1983 Cell-specific regulation of the c-myc gene by lymphocyte mitogens and platelet-derived growth factor. Cell 35 603-610. (doi:10.1016/ 0092-8674(83)90092-2)

MacLean HE, Chiu WM, Ma C, McManus JF, Davey RA, Cameron R, Notini AJ \& Zajac JD 2008a A floxed allele of the androgen receptor gene causes hyperandrogenization in male mice. Physiological Genomics 33 133-137. (doi:10.1152/ physiolgenomics.00260.2007)

MacLean HE, Chiu WS, Notini AJ, Axell AM, Davey RA, McManus JF, Ma C, Plant DR, Lynch GS \& Zajac JD $2008 b$ Impaired skeletal muscle development and function in male, but not female, genomic androgen receptor knockout mice. FASEB Journal 22 2676-2689. (doi:10.1096/fj.08-105726)

Mauras N, Hayes V, Welch S, Rini A, Helgeson K, Dokler M, Veldhuis JD \& Urban RJ 1998 Testosterone deficiency in young men: marked alterations in whole body protein kinetics, strength, and adiposity. Journal of Clinical Endocrinology and Metabolism 83 1886-1892. (doi:10.1210/jc.83.6.1886)

Mulvaney DR, Marple DN \& Merkel RA 1988 Proliferation of skeletal muscle satellite cells after castration and administration of testosterone propionate. Proceedings of the Society for Experimental Biology and Medicine 188 40-45. (doi:10.3181/00379727-188-42704)

Nabeshima Y, Hanaoka K, Hayasaka M, Esumi E, Li S, Nonaka I \& Nabeshima Y 1993 Myogenin gene disruption results in perinatal lethality because of severe muscle defect. Nature $364532-535$. (doi:10.1038/364532a0)

Notini AJ, Davey RA, McManus JF, Bate KL \& Zajac JD 2005 Genomic actions of the androgen receptor are required for normal male sexual differentiation in a mouse model. Journal of Molecular Endocrinology 35 547-555. (doi:10.1677/jme.1.01884)

Ophoff J, Callewaert F, Venken K, De Gendt K, Ohlsson C, GayanRamirez G, Decramer M, Boonen S, Bouillon R, Verhoeven G, et al. $2009 a$ Physical activity in the androgen receptor knockout mouse: evidence for reversal of androgen deficiency on cancellous bone. Biochemical and Biophysical Research Communications 378 139-144. (doi:10.1016/j.bbrc.2008.11.016)

Ophoff J, Van Proeyen K, Callewaert F, De Gendt K, De Bock K, Vanden Bosch A, Verhoeven G, Hespel P \& Vanderschueren D 2009b Androgen signaling in myocytes contributes to the maintenance of muscle mass and fiber type regulation but not to muscle strength or fatigue. Endocrinology 150 3558-3566. (doi:10.1210/en.2008-1509)

Pang TP, Clarke MV, Ghasem-Zadeh A, Lee NK, Davey RA \& MacLean HE 2011 A physiological role for androgen actions in the absence of androgen receptor DNA binding activity. Molecular and Cellular Endocrinology 348 189-197. (doi:10.1016/j.mce.2011.08.017)

Patapoutian A, Yoon JK, Miner JH, Wang S, Stark K \& Wold B 1995 Disruption of the mouse MRF4 gene identifies multiple waves of myogenesis in the myotome. Development 121 3347-3358.

Powers ML \& Florini JR 1975 A direct effect of testosterone on muscle cells in tissue culture. Endocrinology 97 1043-1047. (doi:10.1210/ endo-97-4-1043)

Rana K, Fam BC, Clarke MV, Pang TP, Zajac JD \& MacLean HE 2011 Increased adiposity in DNA binding-dependent androgen receptor knockout male mice associated with decreased voluntary activity and not insulin resistance. American Journal of Physiology: Endocrinology and Metabolism 301 E767-E778. (doi:10.1152/ ajpendo.00584.2010)

Rana K, Lee NK, Zajac JD \& Maclean HE 2014 Expression of androgen receptor target genes in skeletal muscle. Asian Journal of Andrology $\mathbf{1 6}$ 675-683. (doi:10.4103/1008-682X.122861)

Raskin K, de Gendt K, Duittoz A, Liere P, Verhoeven G, Tronche F \& Mhaouty-Kodja S 2009 Conditional inactivation of androgen receptor gene in the nervous system: effects on male behavioral and neuroendocrine responses. Journal of Neuroscience 29 4461-4470. (doi:10.1523/JNEUROSCI.0296-09.2009) 
Rawls A, Morris JH, Rudnicki M, Braun T, Arnold HH, Klein WH \& Olson EN 1995 Myogenin's functions do not overlap with those of MyoD or Myf-5 during mouse embryogenesis. Developmental Biology 172 37-50. (doi:10.1006/dbio.1995.0004)

Rudnicki MA \& Williams BO 2015 Wnt signaling in bone and muscle. Bone 80 60-66. (doi:10.1016/j.bone.2015.02.009)

Schiaffino S \& Mammucari C 2011 Regulation of skeletal muscle growth by the IGF1-Akt/PKB pathway: insights from genetic models. Skeletal Muscle 1 4. (doi:10.1186/2044-5040-1-4)

Schwander M, Leu M, Stumm M, Dorchies OM, Ruegg UT, Schittny J \& Muller U 2003 Beta1 integrins regulate myoblast fusion and sarcomere assembly. Developmental Cell 4 673-685. (doi:10.1016/ S1534-5807(03)00118-7)

Sheffield-Moore M, Urban RJ, Wolf SE, Jiang J, Catlin DH, Herndon DN, Wolfe RR \& Ferrando AA 1999 Short-term oxandrolone administration stimulates net muscle protein synthesis in young men. Journal of Clinical Endocrinology and Metabolism 84 2705-2711. (doi:10.1210/jc.84.8.2705)

Singh R, Artaza JN, Taylor WE, Gonzalez-Cadavid NF \& Bhasin S 2003 Androgens stimulate myogenic differentiation and inhibit adipogenesis in C3H 10T1/2 pluripotent cells through an androgen receptor-mediated pathway. Endocrinology 144 5081-5088. (doi:10.1210/en.2003-0741)

Singh R, Bhasin S, Braga M, Artaza JN, Pervin S, Taylor WE, Krishnan V, Sinha SK, Rajavashisth TB \& Jasuja R 2009 Regulation of myogenic differentiation by androgens: cross talk between androgen receptor/ beta-catenin and follistatin/transforming growth factor-beta signaling pathways. Endocrinology 150 1259-1268. (doi:10.1210/en.2008-0858)

Sinha-Hikim I, Artaza J, Woodhouse L, Gonzalez-Cadavid N, Singh AB, Lee MI, Storer TW, Casaburi R, Shen R \& Bhasin S 2002
Testosterone-induced increase in muscle size in healthy young men is associated with muscle fiber hypertrophy. American Journal of Physiology: Endocrinology and Metabolism 283 E154-E164. (doi:10.1152/ajpendo.00502.2001)

Sinha-Hikim I, Cornford M, Gaytan H, Lee ML \& Bhasin S 2006 Effects of testosterone supplementation on skeletal muscle fiber hypertrophy and satellite cells in community-dwelling older men. Journal of Clinical Endocrinology and Metabolism 91 3024-3033. (doi:10.1210/jc.2006-0357)

Snyder PJ, Peachey H, Hannoush P, Berlin JA, Loh L, Lenrow DA, Holmes JH, Dlewati A, Santanna J, Rosen CJ, et al. 1999 Effect of testosterone treatment on body composition and muscle strength in men over 65 years of age. Journal of Clinical Endocrinology and Metabolism 84 2647-2653. (doi:10.1210/jc.84.8.2647)

Srinivas-Shankar U, Roberts SA, Connolly MJ, O'Connell MD, Adams JE, Oldham JA \& Wu FC 2010 Effects of testosterone on muscle strength, physical function, body composition, and quality of life in intermediate-frail and frail elderly men: a randomized, double-blind, placebo-controlled study. Journal of Clinical Endocrinology and Metabolism 95 639-650. (doi:10.1210/jc.2009-1251)

Wang C, Swerdloff RS, Iranmanesh A, Dobs A, Snyder PJ, Cunningham G, Matsumoto AM, Weber T \& Berman N 2000 Transdermal testosterone gel improves sexual function, mood, muscle strength, and body composition parameters in hypogonadal men. Journal of Clinical Endocrinology and Metabolism 85 2839-2853. (doi:10.1210/jc.85.8.2839)

Wilson EM \& Rotwein P 2006 Control of MyoD function during initiation of muscle differentiation by an autocrine signaling pathway activated by insulin-like growth factor-II. Journal of Biological Chemistry 281 29962-29971. (doi:10.1074/jbc. M605445200)

Received in final form 22 June 2016

Accepted 4 July 2016

Accepted Preprint published online 4 July 2016
๑) 2016 Society for Endocrinology Printed in Great Britain 